DOI: https://doi.org/10.31933/dijms.v2i6

Received: $28^{\text {th }}$ July 2021, Revised: $10^{\text {th }}$ August 2021, Publish: $31^{\text {st }}$ August 2021

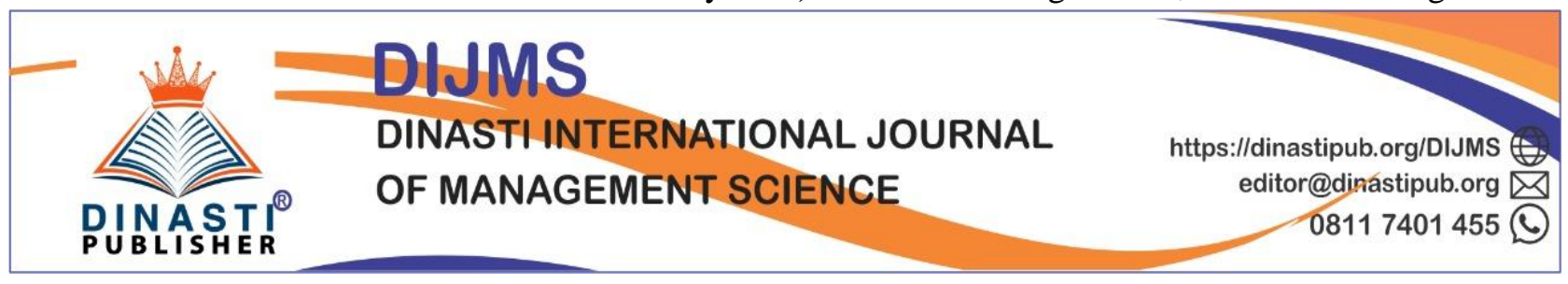

\title{
ANALYSIS OF FACTORS AFFECTING THE DEMAND FOR MORTGAGE CREDIT IN PT. $X$
}

\author{
Syamsu Dairatil Irvan', Dewi Nusraningrum² \\ 1)Universitas Mercu Buana, Jakarta, Indonesia, Syamsu.Irvan@ gmail.com \\ ${ }^{2)}$ Universitas Mercu Buana, Jakarta, Indonesia
}

Corresponding Author: Syamsu Dairatil Irvan

\begin{abstract}
PT X is a financial institution that distributes credit, one of which is mortgage credit or home ownership credit (KPR). The realization of mortgage lending at PT X from 2017 to 2020 has not been able to reach the target due to lack of credit demand. This study analyzes the interest rate, service, procedure, term, guarantee, and technology factors whether they have a significant influence on credit demand. From this study, the results and conclusions of the service factor have a significant influence on credit demand. Factors other than service have an influence on credit demand but not significantly.
\end{abstract}

Keyword: mortgage, demand, credit, interest rate, service, bank

\section{INTRODUCTION}

As a bank that carries out the intermediation function, PT X distributes credit to the public. In general, there are two kinds of credit, namely consumer credit and productive credit. One example of consumer credit disbursed by PT X is motgage credit. Mortgage credit or also known as Home Ownership Credit (KPR) is a loan used to buy a house or to meet consumer needs with collateral/collateral in the form of a house (Sinulingga, 2019). PT X was given a target by management to distribute mortgage loans in 2017 of Rp. 1.9 T, in 2018 of Rp. 1.9 T, in 2019 of Rp. 1.4 T, in 2020 of Rp. 1.3 T. However, the realization of mortgage lending in 2017 was only IDR 1.2 T, in 2018 it was IDR 1.3 T, in 2019 it was IDR $1 \mathrm{~T}$, in 2020 it was IDR 0.8 T. This means that there is a gap in 2017 amounted to IDR 0.7 T, in 2018 it was IDR 0.5 T, in 2019 it was IDR $0.3 \mathrm{~T}$, in 2020 it was IDR 0.5 T. Mortgage loan distribution has not been able to reach the target due to lack of credit demand or credit requests. This research raises the topic of analyzing the factors that influence the demand for credit. From previous studies related to the topic, it is known that there are many factors that influence the demand for credit. This study takes 6 factors, namely interest rates, services, procedures, period of time, guarantees/collateral, and technology. The six 
factors will be tested whether they have a significant effect on the demand for mortgage loans at PT X.

\section{LITERATURE REVIEW}

Credit requests are the amount of money issued by financial institutions that are given to the public as customers in the form of loans within a certain period of time (Suprapto, 2015). Credit request is the amount of credit or loans received by customers in the form of money measured in rupiah units, by providing guarantees in the form of goods or objects whose repayment is determined by the lender (Harianti, 2017). It can be concluded that the request for credit is the amount of money lent by the bank to the public who need funds within a certain period of time with the terms and procedures determined by the bank and material guarantees in the form of goods or objects that have been determined by the bank.

Interest rate is an amount of compensation or remuneration for the use of money by bank customers in a certain credit period. The loan interest rate is the bank's income received from the debtor for the cred it provided (Sandria, 2016). The loan interest rate is a number of fees/prices that must be paid by the customer to the Bank for the use of business capital during a certain time interval (Yasrizal, 2017). The loan interest rate is the average amount of interest that must be paid for taking credit from banks which is expressed in percent every year (Khoirudin, 2017). The loan interest rate is the amount of interest that must be paid for taking credit from banks which is expressed in percent (Pertiwi, 2019). It can be concluded that the interest rate is the cost or price incurred and must be paid by the debtor on the loan that has been received from the bank.

Service is the activity of providing services from one party to another. Good service is a service that is carried out in a friendly, fair, fast, precise and ethical manner so that it meets the needs and satisfaction of those who receive it (Andriani, 2017). Service is any activity that is profitable in a group or entity, and offers satisfaction even though the results are not tied to a physical product (Pertiwi, 2019). It can be concluded that service is an activity of providing services from one party to another who requires services to meet the needs and satisfaction of service recipients.

Credit distribution procedures are a series of interrelated activities to complete a job, namely channeling credit to parties who need funds. The procedure for granting credit is applied to determine whether or not prospective debtors are given credit, so that the risk of bad credit can be minimized as small as possible (Ningtyas, 2015).

The credit period is the credit repayment period that has been agreed between the creditor and the debtor (Kasmir, 2018). Collateral is an obligation that can be valued in money arising from a legal behavior, therefore the law of guarantee is very closely related to the law of objects and cannot even be separated from the law of objects. Collateral in a broad sense is a guarantee that is material and non-material. Material guarantees are material guarantees such as buildings, land, 
vehicles, jewelry, securities. Meanwhile, non-material guarantees, such as personal guarantees. (Pertiwi, 2019).

Technology according to the Big Indonesian Dictionary is a scientific method to achieve practical goals, applied science or the overall means to provide goods needed for the survival and comfort of human life.

\section{RESEARCH METHOD}

This research uses quantitative research with causal analysis method. A causal relationship is a causal relationship. In this study there are independent variables (influence) and dependent variables (influenced). This study has seven variables that will be tested for the relationship where there are six independent variables (independent) namely interest rates (X1), services (X2), procedures (X3), time period (X4), guarantees (X5), and technology (X6). , and the dependent variable (dependent) is the demand for credit $(\mathrm{Y})$. The data collection method used an online questionnaire via Google Form. The population in this study were all Mortgage credit customers totaling 12,344 people. The sample in this study was taken using a simple random sampling technique, namely the sample was carried out at random without regard to the existing strata in the population itself. The number of samples in this study was 100 people, calculated using the Slovin formula as follows:

$$
\begin{aligned}
& \hline n=\frac{N}{1+\left(N \times e^{2}\right)} \\
& \mathrm{n}=12344 /(1+12344 \times 0.12) \\
& \mathrm{n}=99,19=100 \text { Customer } \\
& \text { Information : } \\
& \mathrm{n}=\text { Total of sample } \\
& \mathrm{N}=\text { Total of population } \\
& \mathrm{e}=(\text { error tolerance })
\end{aligned}
$$

The framework of thought in this research is as follows: 


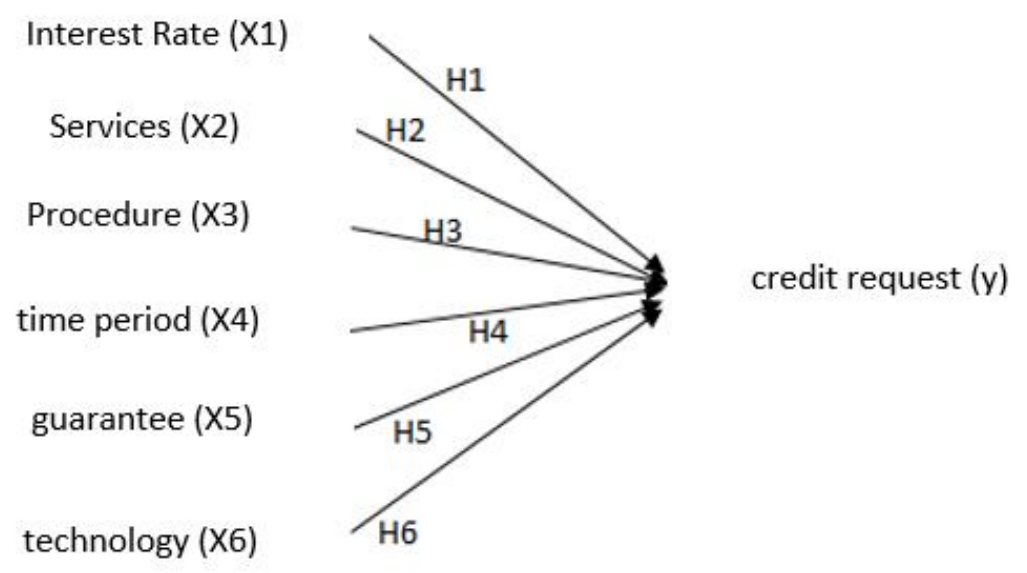

Figure 1. Conceptual Framework

The hypotheses of this research are as follows:

$\mathrm{HO}$ : Interest rate, service, procedure, term, guarantee, and technology does not have a significant effect on credit demand

$\mathrm{H} 1$ : Interest rates have a significant effect on credit demand

$\mathrm{H} 2$ : Service has a significant effect on credit demand

H3: Procedure has a significant effect on credit demand

H4 : The credit period has a significant effect on credit demand

H5: Collateral has a significant effect on credit demand

H6: Technology has a significant effect on credit demand

The analysis in this study uses the Partial Least Square (PLS) analysis method, using the SmartPLS software. PLS analysis consists of two sub models, namely the outer model and the inner model.

The outer model or known as the measurement model tests the validity and reliability. There are two validity tests, namely convergent validity and discriminant validity. It can be said to have convergent validity if the loading factor value is more than 0.7 and the AVE value is more than 0.5 (Ghozali, 2018). It can be said to have discriminant validity if the Cronbach's Alpha value is more than 0.6 and the Composite Reliability value is more than 0.7 (Jogiyanto, 2015).

The inner model or known as the structural model tests the Coefficient of Determination (R2), Goodness of Fit (Q2), and hypothesis testing. The value of Goodness of Fit (Q2) in the PLS analysis has the same meaning as the coefficient of determination (R2) in the regression analysis. It is recommended that the value of the Coefficient of Determination (R2) and Goodness of Fit (Q2) is more than 0.5 with a range between 0 to 1 . Test the hypothesis using the T-table value and the T-statistical value and $\mathrm{P}$ Value where if the T-statistic value is greater than T-table value and $\mathrm{P}-\mathrm{V}$ alue $<0.5$ means the effect is significant and the hypothesis is supported or accepted (Ha is 
accepted, H0 is rejected). However, if the T-statistic value is smaller than the T-table value and PValue $>0.5$, it means that the effect is not significant and the hypothesis is not supported or rejected (Ha is rejected, $\mathrm{H} 0$ is accepted). With a confidence level or significance level of $95 \%(\alpha 0.05)$, the T-table value used to test the hypothesis is 1.96 .

\section{RESEARCH AND DISCUSSION \\ Testing Outer Model}

From the validity test, the results of the correlation between the indicator and its construct show the outer loading value $>0.7$, the cross loading value $>0.7$ and the AVE value $>0.5$, meaning that the indicator has a good correlation with the construct or all ind icators can be said to be valid. From the reliability test, the results of the correlation between the indicators and their constructs show the Composite Reliability value $>0.7$ and Cronbach's Alpha > 0.7, meaning that each indicator of each variable can be said to be reliable to measure the variable.

\section{Inner Model Test}

The coefficient of determination (R2) and Goodness of Fit (Q2) is 0.56, meaning that the influence of each variable $\mathrm{X}$ on $\mathrm{Y}$ is more than $50 \%$. :

Table. 1 Inner Model

\begin{tabular}{|l|r|r|l|}
\hline Hipothesys & \multicolumn{1}{|c|}{ T Statistic } & \multicolumn{1}{c|}{ P Value } & Conclusion \\
\hline H1 & 0.165 & 0.869 & H1 Reject \\
\hline H2 & 8.801 & 0.000 & H2 Accept \\
\hline H3 & 0.782 & 0.435 & H3 Reject \\
\hline H4 & 0.518 & 0.605 & H4 Reject \\
\hline H5 & 0.669 & 0.504 & H5 Reject \\
\hline H6 & 0.753 & 0.452 & H6 Reject \\
\hline
\end{tabular}

\section{CONCLUSION}

Based on the results of the research that has been done, it can be concluded as follows:

- The influence of service is significant on Credit Demand because the service is considered the first impression by the customer (customer) so that service is an important factor that must always be considered by the company.

- The effect of interest rates is not significant on Credit Demand because Mortgage credit customers view house or land assets as basic necessities of life that must be met so that demand for mortgage loans tends to be less affected by variations in interest rates.

- The effect of the procedure is not significant on Credit Requests because customers must continue to follow the procedures set by the bank so that cred it applications can be accepted and processed.

- The effect of time period is not significant on Credit Request because the customer has the freedom to choose the desired period of time. Customers with stable and adequate income 
and not spending too much tend to choose a short period of time, while customers with a moderate income and lots of expenses tend to choose a relatively long period of time.

- The effect of collateral is not significant on Credit Requests because collateral is a basic requirement that must be met by all customers in ord er for credit applications to be accepted and processed.

- The influence of technology is not significant on Credit Demand because services that are not through technology are still more dominant because of the direct interaction between bank officers and customers there is a positive impact desired by the bank due to the achievement of a better understanding to customers and a more persuasive approach to customers .

\section{REFERENCE}

Harianti. (2017). Analisis Faktor-Faktor Yang Mempengaruhi Permintaan Kredit Cepat Aman Pada Pt. Pegadaian Di Kota Makassar.

Kasmir. S.E., M.M. (2018). Bank dan Lembaga Keuangan Lainnya. Jakarta: PT Raja Grafindo Persada.

Khoirudin, R. (2017). Determinan Yang Mempengaruhi Jumlah Permintaan Kredit Pemilikan Rumah di Indonesia.

Ningtyas, S.A. (2015). Analisis Prosedur Pemberian Kredit untuk Menghindari Kredit Macet.

Pertiwi, Yuli M. (2019). Analisis Faktor-Faktor Yang Mempengaruhi Permintaan Kredit Oleh Pegawai Negeri Sipil (PNS) Di Kota Payakumbuh.

Sandria, D., Adnan, N., Yuliana, S. (2016). Analisis faktor yang mempengaruhi permintaan kredit pemilikan rumah (KPR) di Kota Palembang: Studi Kasus : KPR Bank BTN.

Sinulingga, M.Y. (2019). Analisis Faktor-faktor Yang Mempengaruhi Permintaan Kredit Pemilikan Rumah (KPR) pada Bank Pemerintah Kota Medan. Universitas Sumatera Utara.

Yasrizal. (2017). Faktor-faktor yang mempengaruhi permintaan kredit Usaha Mikro Kecil Menengah (UMKM) di Provinsi Aceh. 